\title{
Var Grundtvigs nadversyn luthersk?
}

\author{
Af Christian Thodberg
}

I hele sin tid som præst fremhævede Grundtvig sig selv som lutheraner. Det galder hans pietistiske periode 1810-20, men også senere, hvor han kunne erklære, at han alle forskelle til trods videreforte Luthers intentioner.

Men var Grundtvig egentlig lutheraner? Da Hal Koch i begyndelsen af 1950'erne i Krogerup Højskoles årsskrift anklagede Grundtvig og det 19. århundrede for at have svigtet medmennesket og dermed Luthers livsopfattelse og arv, skabte det en indigneret modlitteratur. Der kan tænkes på Henning Høirups bog Fra døden til livet. Allerede tidligere havde f.eks. Regin Prenter i Grundtvig-Studier 1948 - lyst Grundtvigs forkyndelse i kuld og køn som luthersk, og når Kaj Thaning senere i sin disputats skildrede Grundtvigs opgør med det lutherske, var det mere den lutherske ortodoxi end Luther selv, han tænkte på.

Man når næppe videre med at besvare dette spørgsmål, med mindre man tager et enkelt perspektiv op. I denne forbindelse vil jeg pege på nadveren som et egnet udgangspunkt.

Som bekendt knytter Grundtvig ofte dåben og nadveren sammen, og det er derfor også rimeligt her til en begyndelse at kaste et blik på Grundtvigs dåbssyn, der ligger klarest $i$ dagen. En undersøgelse af Grundtvigs dåbssyn viser, at han knytter sig stærkt til ritualets ordlyd. Man kunne kalde Grundtvig den evangeliske ritualist: Alle ord og udtryk i ritualet med personligt spørgende og tiltalende karakter bliver for ham i en kort form evangeliet eller "ordet «. Sådan havde han selv erfaret det. Forsøget på historisk og videnskabeligt at godtgøre, at disse bestemte ord hidrører fra Jesus selv, er i grunden sekundært. Hovedsagen er, at han har erfaret ritualordene som evangeliets eksistentielle 
tiltale. I dåbsritualet havde han også meget at øse af, og dåben fik en så central betydning for Grundtvig, at nadveren kom til at stå lidt i skyggen.

Anderledes udtrykt: Dåben passer til Grundtvigs syn. Han er også i overensstemmelse med luthersk lære, når det drejer sig om dåbsvandet, dåbens element, der - som Luther siger - er indfattet $\mathrm{i}$ ordet. Dåbens element kommer med andre ord ikke $\mathrm{i}$ vejen for den fremhævelse af dåbens ordkarakter, der er Grundtvigs anliggende. $\mathrm{Og}$ han kommer $\mathrm{i}$ det store og hele ikke $\mathrm{i}$ konflikt med det lutherske syn overhovedet.

Men når han i forbindelse med dåben kan tale så stærkt om ordet, om det hørlige og usynlige på det synliges og legemliges bekostning, kommer han i forbindelse med altergangen helt naturligt i modsætning til det lutherske nadversyn, hvor ordet på den ene side og brødet og vinen på den anden side har hver sin vægt. Tydeligst kommer denne polarisering frem, når Luther på den ene side kan sige: "Evangeliet, Gudsordet, tilkommer dog den allerhøjeste ære, fordi Gud deri er Kristus nærmere end $i$ brød og vin "-og på den anden side: "Den mund, den hals, den krop, som æder Kristi legeme, skal også have sin nytte deraf, så han lever evigt og opstår på den yderste dag til evig salighed ", uden at der for Luther selv er en indre modsigelse imellem de to udsagn. Der er blot tale om to forskellige fronter og opgør.

Som den evangeliske ritualist kommer Grundtvig med andre ord i klemme, hvad angår nadverelementerne. Hans forhold til dåbsritualet er positivt inspireret, således som jeg i anden sammenhæng har forsøgt at skildre det, men hans forhold til nadverritualet bliver tilsvarende negativt. Han er selv opmærksom på det: "Det eneste man kunde udsætte på den Lutherske Talebrug, maatte da være, at ikke hele Vægten ved Nadveren, som ved Daaben, lagdes paa Ordet, og Aanden, saa Brødet og Vinen i Nadveren kom saanær som mueligt i samme Forhold dertil, som Vandet i Daaben, der, efter Luthers uforbederlige Udtryk, skylder Sammenføielsen med Ordet al sin Delagtighed i Gienfødelsen" (Nordisk Tidsskrift f. christelig Theologi, IV, 137f (1842)).

Det er den lutherske "talebrug ", der generer Grundtvig - ikke Luthers intention. Sagt med andre ord: Grundtvig føler, at det lutherske nadverritual hæmmer ham i modsætning til dåbsritualet. Dermed være ikke sagt, at han ikke făr noget ud af nadve- 
ren, men man kan sige, at han bevidst eller ubevidst kommer til at lægge noget andet ind i det nadverritual, som han som præst skulle bruge den ene søndag efter den anden. Derfor bliver en nærlæsning af Grundtvigs udsagn om nadveren dobbelt interessant og spændende.

Forsøger vi at gå kronologisk til værks, kan man spørge om Grundtvigs normalforudsætninger, hvad angår nadveren. Her kan det nævnes, at da Grundtvig den 3. oktober 1803 var oppe til den skriftlige del af teologisk embedsskamen, fik han følgende opgave: Giv en fremstilling af oprindelsen til dogmet om offerhandlingen $i$ nadveren. Han afleverede opgaven blank, fordi han efter eget udsagn ikke var i stand til at skrive den. Det kunne tyde på, at hans normalforudsæetninger var minimale.

Første gang, Grundtvig ytrer sig om nadveren, er i afhandlingen Om Religion og Liturgie (skrevet 1806, trykt 1807). Den var foranlediget af biskop Boisens Plan til Forbedring ved den offentlige Gudsdyrkelse, men har iøvrigt som baggrund Grundtvigs romantiske af Schelling påvirkede vækkelse: Den synlige og sanselige verden er et billede af og et symbol på den egentlige virkelighed. Den evnerige kunstner viser bedst vej til denne virkelighed, men det samme gælder religionen og liturgien, og som symbol på den bagved liggende virkelighed bliver den af Boisen så forhadte gamle gudstjeneste rehabiliteret. Jo mere mystisk og dybsindig gudstjenesten er, des bedre. Man mærker her de første ansatser til en ultramontan gudstjenestevækkelse i romantikkens kølvand. Derfor vedkender Grundtvig sig ganske særligt dåben og nadveren i den gamle form. Allerede her i denne i sandhed besynderlige afhandling mærkes, at det måske kan være frugtbart at tage sit udgangspunkt i det faste og uforanderlige hos Grundtvig trods alle tilsyneladende gennembrud og opgør. Afhandlingen fra 1806/7 er ikke et særligt originalt arbejde fra Grundtvigs hånd; det viser, at han er et barn af sin tid. Her er et udgangspunkt, som han aldrig forlader, men som han efterhånden fylder med et overraskende og helt nyt indhold. Hvad Grundtvig på denne tid siger om nadveren, er stort set, hvad han går ind for resten af sit liv, når man ser bort fra den tågede og overspæendte form.

M.h.t. nadveren vil han have fjernet den forrudgående absolution, et krav, han aldrig frafaldt. Vigtigere er det dog, at Grundt- 
vig går ind for afskaffelsen af uddelingsordene, der på hans tid lød: "Dette er Jesu sande Legeme/Blod". Med disse ord nærmer man sig nemlig "Transubstantiationens bespottelige Lære", og om forholdet mellem katolsk og luthersk lære siger Grundtvig ".... at Forskiellen vel kun turde være sophistisk " (Værker i Udvalg, I 135). Han fortsætter og siger:

"Ville vi fængsle det Evige i det Endeliges Produktioner, ville vi gennem Munden nyde det Allerhelligste, der kun ved Troen kan blive os til Deel, da har Spotteren Voltære Ret til at haane os; da nedbrydes Sandsen af Christi Læres høieste Hemmelighed; thi vi søge da at fæste det Himmelske til Jorden, istedet for at vi, hævede ved dets gudelige $\mathrm{Kraft}$, skulde forene os med det.

Hvorfor kan ikke Sakramentet uddeles taus, efterat Indstiftelsens Ord ere læste, saaledes som Skik var i den ældre danske protestantiske Kirke? Eller, hvis Ord skulle bruges, var det vel Kætterie at ligne de Reformeerte, hvis Formel: det betyder, dog i Sandhed betyder langt mere end vores? Eller, om vi ingen af Delene ville, hvad hindrer os da fra, at sige med Paulus: Velsignelsens Kalk, som vi velsigne, er Christi Blods Samfund, det Brød som vi bryde er Christi Legems Samfund?

Vilde Paulus have talt saaledes, dersom han havde troet, som de, der forfattede vor Confession, at Christi Legeme i, med og under Brødet annammedes i Munden, og - vi gyse ved Tanken - knuses imellem Tænderne?.....

Ville vi ikke erkiende Sandheden af Udsagnet: Bogstaven ihielslaaer, men Aanden giør levende, fordi dette som Alt, nyelig misbrugtes, for dermed, om mueligt, at dræbe Aanden selv? " (I 135-36).

Den dristighed at kræve uddelingsordene fjernet hæver Grundtvig sig ikke senere op til: Derimod omtolker eller fortrænger han ordene og deres mening sidenhen - i 1837 - hvilket vi om lidt vender tilbage til.

Med distinktionen synlig/usynlig og legemlig/ulegemelig taler Grundtvig sin egen tids sprog, og der er ikke tvivl om, at han her - i 1806/7 - står på linje med Karlstad, Zwingli og sværmerne og rammes af Luthers straffedom fra sidst i 1520'erne. Omend dette er hans baggrund, som han faktisk ikke forlader, fylder han dog sidenhen sit nadversyn med et indhold, der hverken er typisk luthersk eller særligt præget af det 19.århundrede. Foreløbig 
er han tydeligvis på kant med det ortodoxe nadversyn, der for ham går $\mathrm{i}$ eet med den foragtede katolske lære, for "Forskiellen turde være sophistisk «.

Den lutherske vakkelse i 1810 burde have sat sig i spor i Grundtvigs syn på nadveren, men faktisk spiller altergangen ikke nogen afgørende rolle for ham. Vægten kommer i prædikenerne 1811-13 i den grad til at hvile på beredelsen og ihukommelsen, d.v.s. på en pietistisk farvet subjektiv betingethed, at han i grunden aldrig kommer til sagen, altergangen selv. Altergangens opgave er først og fremmest at justere de troendes tro, så de ikke går til alters "som Kvæget til Truget ", som det gentagne gange siges. Altergangen er blevet den nidkære præsts nåleøje.

For at forstå kontinuiteten i Grundtvigs udvikling er det værd at mærke sig, at han i grunden altid er optaget af de samme motiver og problemer. Hans udvikling består snarere $i$ en ommøblering af de kendte og fortrolige ting end af egentlige "nyheder ". F.eks. findes tanken om nadveren som det eskatologiske måltid allerede på denne tid, men karakteristisk nok ikke i forbindelse med skærtorsdagprædikenerne, men i juleprædikenerne, hvor Grundtvig i grunden altid er besjælet af den samme barnlige fromhed og glæde. Der tænkes her på juledagsprædikenen 1813, hvor juleaftensmåltidet i Udby Præstegård i barndommens dage bliver et billede på den himmelske altergang og det på en ægte eskatologisk måde. Den første begyndelse og den sluttelige fuldendelse falder sammen:

"Jo visselig, vi vare andre Mennesker i disse Timer, og hvad vi havde gjort vel tusinde Gange, det var for os, som om det gjordes første Gang, aldrig brændte Lyset os saa klart, aldrig var Maaltids Timen os saa kjær og vigtig, som den Juleaften, og naar vi satte os til Bordet med gudfrygtige Forældre, tugtig og høvisk, som Børn dengang sad, og foldede de smaa Hænder, og bad vort: Mad i Jesu Navn! som Børn dengang lærde af de fromme Mødre; ja visselig da saae vi en straalende Skygge af Julenadveren med Abraham, Isak og Jakob i Himmeriges Rige. Vi ginge til Hvile med det Ønske, at vi maatte vaaget til Midnat og seet, hvad Man sagde, Kvæget reise sig i Frelserens Fødselstime, vi vaagnede med en glædelig Fest i Hjerte og paa Tunge. Ja I Elskelige! Meget var herom at sige, og om de Glimt af 
patriarkalske og apostoliske Dage, som vare tilsyne den ganske Juletid,...."

(Bibelske Prædikener 1816, s. 87-88).

Her er Grundtvig sin egen menneskelige virkelighed tro, men først en snes år senere vover han at gøre nadveren i kirken til den himmelske altergang. I grunden har visionen dog altid eksisteret hos ham.

Fra og med 1821 afstrejfes i prædikenerne det biblicistisk-pietistiske præg til fordel for nye tankegange og større perspektiver. Det romantiske billedsprog fra ungdommens dage tages op igen, men nu som et hjælpemiddel til at opnå større klarhed om kristendommens sandhed. Bibelen er ikke længere identisk med Guds ord og Kristus, men bibelen rummer billeder, der peger hen $\mathrm{i}$ retning af den guddommelige virkelighed. Overhovedet står en grundig analyse af Grundtvigs prædikener fra 1821-25 som en nødvendig forudsætning for en virkelig forståelse af hans sakramentsyn. Her skal udviklingen kun skitseres. Det er f.eks. nok en gang de synlige nadverelementer, han slås med, bl.a. i den utrykte skærtorsdagsprædiken fra 1823: "Vi må ..... " betænke, at vore Sakramenter vel ere Tegn, saavelsom Jødernes, skiøndt af en klarere høiere Art, men at de ingenlunde ere blotte Tegn, men tillige noget langt Større. De ere Tegn forsaavidt der med synlige Ting skeer en legemlig Handling med en høiere billedlig Betydning forsaavidt nemlig Vandet $\mathrm{i}$ Daaben betegner den rensende helliggiørende Aand, som Gud i Jesu Navn vil udgyde over os, og forsaavidt Brød og Viin i Nadveren betegner Frelseren, som hengav sit Legeme og udøste sit Blod for os. Men med disse synlige Ting og Tegn er noget Usynligt forbundet; thi vore Sakramenter forvaltes ikke tause, men under Fremførelse af det underfuld Usynlige, som er lagt paa vor Tunge til at forbinde Aand og Legeme, det er Ordet, og her ikke vort afmægtige Ord, men Jesu Almagts-Ord om hvilke han vidner: de ere Liv og Aand."

Det er ordet, der "knytter os til Gud og Frelseren i Aand og Sandhed,...». Ordet åbenbarer sakramenternes egentlig virkelighed. Når vi derfor grunder over sakramenterne og måske stirrer os blinde på den ydre skikkelse, siger Gr.: "Skyggerne forsvandt i Legemet, men hvad de havde dunkelt betegnet, det aabenbare- 
des klarlig i Aand og Sandhed, det udgik i Ordet med giennemsigtige synlige Billeder til Frelserens Menighed «. Og i marginen står karakteristisk nok: "Naar Solen staaer lodret over Legemet, har det ingen Skygge".

Med "ordet" ville den lutherske ortodoxi her tænke på Indstiftelsesordene og pege på nadverens kontante legemlighed i det bestemte brød og den bestemte vin. Men Grundtvig vil have, at Indstiftelsesordene skal pege på den usynlige virkelighed. Ligesom alt andet synligt er nadverens brød og vin også billeder, men det er billeder af særlig art i kraft af ordet.

Ordet giver menigheden "gennemsigtige billeder «. Billederne, det synlige, skyggerne, bliver opklaret af ordet. Det romantiske billedsprog er på vej til at blive suppleret af et andet "sprog". Men hvori består det? hvad skal man forstå ved "ordet «? Det udvikles i den følgende tid. "Ordet " tydeliggøres og konkretiseres i form af proklamerende skriftsteder, f.eks. "Aanden kommer vor Magtesløshed til Hjelp« (Rom. 8,26). Denne bestemte sætning bliver "ordet", d.v.s. hvad hjertet kræver, men naturligvis kun i en bestemt prædikens sammenhæng.

I løbet af 1823 mærkes, hvordan Grundtvig er på vej til De Levendes Land, der bliver til i maj/juni 1824 tydeligvis på baggrund af et "proklamerende" ord, her Johs. 3,16: "Således elskede Gud verden..." og andre skriftsteder. ${ }^{2}$

I Søndagsbogen fra 20'ernes sidste halvdel udformes det syn på "ordet " eller det levende ord, som blev det bærende i resten af Grundtvigs liv. Det kan anskueliggøres i form af en summarisk hermeneutisk model, der beskriver strukturen i Grundtvigs prædikener her og i 30'erne. Heraf fremgår omsider, hvad "det levende ord " materialt er (se næste side):

På venstre side ses øverst de "forkyndelsesproklamationer", der hyppigst forekommer i den tidligste tid. Exemplerne kan suppleres. Derefter følger en serie forkyndelses-imperativer, først verdslige eller folkelige, dernæst bibelske. Disse imperativer er konkrete udtryk for "Ordet i Kraft". I dem koncentreres forkyndelsen, især $\mathrm{i}$ forbindelse med underberetningerne.

Helt afgørende er imidlertid, at disse proklamationer og imperativer med voksende styrke i prædikenerne aktualiseres $i$ de ritual- og gudstjeneste-ord, der opføres på højre side i oversigten. De bliver den faste tolkningsmodel i prædikenerne, for $\mathrm{i}$ disse 
Forkyndelsesproklamationer:

Således elskede Gud verden

(Johs. 3,16)

De er døde som stod barnet efter livet (Matt. 2,20b)

Forkyndelsesimperativer:

(1) "Verdslige«:

Guds Fred!

Glædelig jul!

Glædeligt nytår!

(2) Bibelske:

Bliv til!

Adam! Hvor er du?

Frygt ikke!

Græd ikke!

Stå op!

Kom herud!

Gå!

Kom!

Far ud!

Luk dig op! Effata!

Bliv seende

Søg Herren...!

Bed og bank!

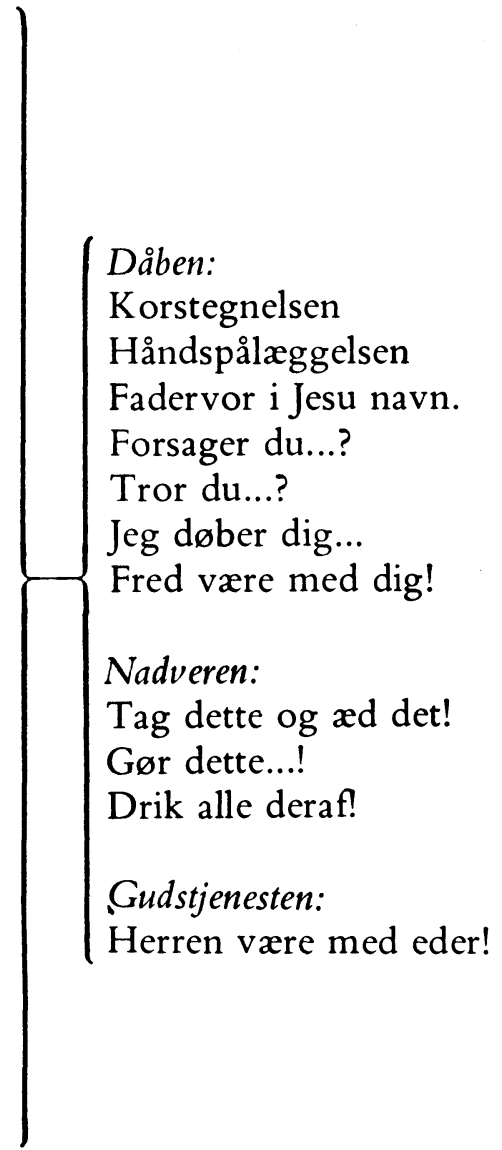

ritual- og gudstjeneste-ord er Kristus nærværende i sin menighed.

Det levende ords udformning i den beskrevne model arbejder Grundtvig med især i 30'erne, og her når udviklingen sit højdepunkt i foråret 1837. Det drejer sig netop her om ordets exklusive kristologiske karakter. Kristus er nærværende i ordet og kun dær. I forbindelse med dåben volder det som næunt ikke vanskeligheder, bl.a. fordi dåbsvandet som element ikke i luthersk tradition spiller nogen rolle. Men i forbindelse med nadveren bliver krisen akut. Hvor er Herrens legeme i nadveren? Ud fra den hermeneutiske model synes det klart, at opmærksomheden koncentreres om nadverritualet, heraf Indstiftelsesordene og heraf igen de befalende ord: Tag dette og aed det! Gor dette til min 
ihukommelse! Drik alle deraf! Men hvordan forholder denne ord-teologi sig til det lutherske nadversyn?

Netop fordi Grundtvig i sit sakramentsyn føler sig bundet af skriften og af traditionen, kan det være vanskeligt at gennemskue ham. Vanskelighederne bliver ikke mindre af, at de afgørende vidnesbyrd i prædikenerne endnu ikke er trykt, og at andre trykte vidnesbyrd f.eks. i salmerne, såvidt jeg kan se, har været ret upåagtede.

For at komme ind i problematikken må man indse, at Grundtvig først og fremmest er en vældig lutheraner i det negative, dvs. når han skal give udtryk for, hvad det lutherske ikke er.

I skærtorsdagsprædikenen 1835 får de reformerte et ord med på vejen: "...de veed ikke Skjel paa Herrens Legeme... sige til hinanden: det betyder og betegner kun hans Legeme og Blod, skjønt de nylig selv har gentaget hans ord: tager hen, xder, det er mit Legeme! drikker alle heraf, det er mit Blod! og det er jo soleklart, at hvem der paastaar, han kun har en Skygge for sig af Herrens Bord, han kunde i det højeste ogsaa kun faa Skyggen af hans Nadvere; men han faar ikke en Gang den, fordi han forsynder sig ved, trods Herrens Ord, at tage det virkelige for en Skygge, Naademidlet for et Skuespil " (Prædikener...i Frederiks-Kirken 1832-39, side 283-84).

Her bliver det reformerte udtryk betegner eller significat kraftigt imødegået, for kraftigt, for det er på nippet til at ramme Grundtvig selv.

Efter at have præciseret fronten til venstre mod kalvinisterne markeres fronten til højre mod katolikkerne: "... man tager sig formastelig paa, selv, med Signen og Manen, at skabe et Herrens Bord, tager sig paa at forvandle ikke blot Brød til Kjød og Vin til Blod, men til Herrens Legem og Blod, uagtet Erfaring øjensynlig viser, det mislykkes aldeles. Naar de altsaa fik alt, hvad de vil modtage, da fik de et naturligt Stykke Kjød under Skikkelse af Brød. Og i den Anledning siger Herren netop: Kjødet nytter ikke, det er Aanden, som gjør levende, og Apostelen siger: de æde sig selv til Doms, i det [de] ikke gjør Forskjel paa Herrens Legeme og deres eget" (sst., side 284).

Grundtvig taler næsten som i 1806. Hans front mod katolikkerne er stadig den skarpest formulerede. Ud fra det netop an- 
førte kan man tænke på Grundvigs salme Herre, hvor skal vi ga hen (salmebogen nr. 418) og ordene:

ÆD MIT KØD OG DRIK MIT BLOD!

og med det samme indse, at Grundtvig med disse ord må mene noget andet end det bogstavelige, selv om det langt fra fremgår af salmen i den dårlige redaktion, den i salmebogen fremtræder i. ${ }^{3}$

Netop når fronterne mod venstre og højre er trukket så hårdt op, er forventningerne tilsvarende store til, hvad Grundtvig har at sige om sin middelvej, det, som han kalder det lutherske. Han siger i samme prædiken i 1835 (side 284):

"Altsaa, mine Venner! skal under disse Omstændigheder nogen have Gavn af Herrens Bord, da maa det være os saakaldte Lutheranere, som med Luther og Fædrene enfoldig tro, at han, som har sagt det, han baade kan og vil gjøre det, skjønt vi ej formaa at udgrunde, hvorledes; saa naar vi tage ham paa Ordet, da har vi ham vist, og blive, som Apostelen siger om Kristus og Menigheden, af hans Kjød og Ben, faa Del i ham baade med Sjæl og Legeme, saa vor Sjæl lever op i hans Aand og fryder sig i sin Gud og Frelser, og Legemet indvies til Uforkrænkelighed, til en ærefuld Opstandelse ligesom hans".

Den ortodoxe lutheraner vil her høre sit eget standpunkt udtalt med kendte formuleringer. Og dog. Man undrer sig over, hvor lidt positivt Grundtvig udtrykker sig efter de voldsomt polemiske udfald.

Læg nøje mærke til, hvordan Grundtvig udtrykker sig: vi skal tage Herren på ordet, det eneste kursiverede ord i citatet. Når vi tager ham på ordet, har vi ham sikkert og bliver af hans kød og ben, et ordpar, hentet fra Evas skabelse af Adam i 1. Mosebogs 2. kap., som Grundtvig uafladelig bruger til at betegne den enhed med Kristus, der kommer i stand ved nadveren. Vi skal få del i ham med sjæl og legeme, fortsætter han, så vor sjæl oplives og legemet indvies til opstandelsen.

Nadverens eget begrebspar, Kristi legeme og blod, undgår Grundtvig som regel bortset fra de ordrette citater af Indstiftelsesordene, der er så hyppige, at vi straks skal vende tilbage til fænomenet. Jeg understreger begrebsparret Kristi legeme og blod. I stedet bruger Grundtvig, når han ikke føler sig bundet af den præcise citation, med forkærlighed det netop nævnte begrebspar 
kød og ben og det johannæiske kød og blod. Det er altså især ordet legeme, der er ham imod. Foruden om menneskets legeme bruger han fortrinsvis ordet legeme i betydningen fallesskab, ganske særligt med udgangspunkt i vendinger fra Efeserbrevet.

Nadveren giver livsfællesskab med Herren med særligt henblik på livets fuldendelse med opstandelsen. Det er det samme livsfællesskab, hvis begyndelse ved dåben markeres med det tilsigende og tilspørgende ord. Men hvordan sker det ved nadveren? Grundtvig distancerer sig fra uddelingsordene i samme grad, som han undgår ordet legeme, og dermed distancerer han sig fra nadverens synlige side. Han knytter sig især til formuleringer fra Johannesevangeliet kap. 6 og dermed til en opfattelse af nadveren, der gør den åndelige spisning til hovedsagen. Selv om han især knytter sig til den "sakramentalistiske" del af kap. 6 , nemlig v. $51 \mathrm{c}-58$, er det dog klart, at det er den åndelige forståelse, han hylder. Ellers ville han ikke med så stor kraft have afvist den bastante katolske sakramentalistiske opfattelse.

Derfor kan han i prædikenen: Herrens Bord i Søndags-Bogen, bind 3, sige om livets kilde og livets flod, at de "umuelig af Verden ... kan ... beføles i Brødet, vi æde, eller smages i Vinen, vi drikker ved Herrens Bord, da de kun udspringe og henstrømme i Ordet, som udgaaer af Herrens Mund og indgaaer i de Troendes Hjerte, bærende Alt hvad det byder ..." (2. udg., s. 233).

Alt, hvad der her er fremført, er en summarisk sammenfatning af en indgående analyse af Grundtvigs ordbrug i forbindelse med nadveren. Billedet er selvfølgelig mere nuanceret, end jeg her kan gå ind på det. Resultatet bliver dog det samme: Grundtvig er $\mathrm{i}$ en tilbundsgående konflikt med sit lutherske nadverritual og den lutherske nadverlære, men bundet som han er af sin tradition, taler han sjældent rent ud, men hellere ved siden af. Man skal nærlæse ham og lægge nøje mærke til, hvad han ikke siger.

I foråret 1837 tager han imidlertid bladet fra munden. Det sker i en periode fra januar til april, hvor Grundtvig er præget af en usædvanlig opstemthed. Med rette kan man kalde det "den græske vækkelse", for under indtryk af sit arbejde med oversættelsen af græske salmer bliver Grundtvig i sjælden grad sig sine 
egne synspunkter bevidst. Den ydre påvirkning forstærker en trang til klarhed. ${ }^{4}$

Trangen spores allerede i det foregående efterår 1836 med prædikenen på 16. søndag efter trinitatis (18. september) over beretningen om enkens søn i Nain. Med henblik på det flg. henvises til den hermeneutiske model på side 14, fordi prædikenen er et skoleeksempel på modellen.

Prædikenens overskrift er "Grad ikke! " - en opfordring, der i menneskers mund er tom og magtesløs, fordi ingen jordisk stemme kan trøste i den afgørende nød: sorgen over døden. Men sagt af Gud selv er det det trøsterigeste ord af alle. Det lærer erfaringen os; først og fremmest hjertet mærker det. Hvis vi vil åbne øren og hjerte, vil vi også erfare - siger Grundtvig - „Herrens virkelige Nærværelse», hvor han er selv til stede: "Jeg siger: saa vist som Jesus Christus er Guds eenbaarne Søn og saavist som den Daab, vi døbes med, og den hellige Nadvere, vi indbydes til er indstiftede af Ham, saavist er han ogsaa selv tilstæde overalt, hvor der døbes, bespises og læedskes paa hans Vegne og med hans Ord, og det er ham selv, der taler til dem, der vil høre hans Røst, ham selv der spørger: troer du, ham selv der siger til den Troende: jeg døber dig i Navnet Faderens og Sønnens og den Hellig-Aands ham selv der byder de Troende og Døbte til sit Bord og siger til dem: tager hen og æder, det er mit Legeme, som gives for eder, drikker alle heraf denne er den ny Pagts Kalk i mit Blod, som udøses for eder til Syndernes Forladelse."

Altså: "græd ikke!" aktualiseres i de personligt henvendende ritualord. Der er "Herrens virkelige Nærværelse", et ofte forekommende udtryk.

Alene udtrykket "Nærværelse" bringer $\mathrm{i}$ erindring den terminologi, der sædvanligvis i den lutherske ortodoxi anvendes om Kristi substantielle nærvær i nadverens brød og vin: realpresens. Og det er just dette problem Grundtvig nærmer sig - næste gang i prædikenen på sexagesima søndag (29.januar 1837). Udgangspunkt er teksten om de fire slags sædejord (Lukas 4,4-16), og overskriften lyder "Saden er Guds Ord! ". Prædikenen begynder således:

"Verdens Skriftkloge ryste vel paa Hovedet ad vor grove Uvidenhed, naar vi skielnede skarpt mellem er og betyder, og giør de det selv ved Nadveren, hvor de aabenbar selv har skildt sig 
ad, hvad ikke da ved Dagens Evangelium, hvor vi hverken kan eller vil nægte, at Herren taler lignelsesviis. Men ikke desmindre blive vi dog med vore Fædre ved at sige: Sæden er Guds Ord og at lægge alt det Eftertryk og al den Vægt vï kan paa det er baade her og overalt hvor Talen er om Guds Naade-Midler og Naade-Virkninger i vor Herres Jesu Christi Kirke og Menighed."

Grundtvig leder straks tanken hen på nadveren. Lutheranere og reformerte er uenige om meningen med er i nadverens tydelige ord: det er mit legeme, som gives for jer, o.s.v. - striden om est og significat. Grundtvig føler sig hævet over denne diskussion: "For end videre at oplyse dette med et bekiendt Exempel, skal vi sige til de Skriftkloge, der vil snakke os af med Forskiellen imellem at være og blot at betyde, skal vi forsikre dem, at Brødet og Vinen i Nadveren, naar vi betragte dem for sig selv ogsaa i vore Øine kun betyde og betegne Christi Legeme og Blod, som den jordiske Næring og Styrkelse betyder og betegner den Himmelske, men at vi desuagtet nødvendig maae lægge al muelig Vægt paa Herrens Ord til os, naar han siger: tager, æder! det er mit Legeme, drikke Alle heraf, det er den ny Pagts Kalk i mit Blod, lægge al muelig Vægt herpaa, fordi det er Herrens eneste levende Ord til os, som vi gaae og staae og høre i Verden, om den virkelige Forening mellem Ham og os, der maa finde Sted, naar alt skal blive Vores, ligesom alt Vores blev Hans, da vi ved Daaben lovede Ham evig Troskab og optoges i Hans Menighed indplantedes som Kviste i Ham, som det sande Vintræ -«.

Brødet og vinen i nadveren er som andre jordiske ting kun skygger og billeder, der højst kan betyde og betegne det himmelske. Alene de befalende ord ved nadveren kan bringe frelsens forening med Herren i stand. Grundtvig er ikke kalvinist; han kan ikke nøjes med betyder alene. Men til gengæld finder han ikke som lutheranerne sit er i forbindelse med brødet og vinen, men $\mathrm{i}$ de befalende ord $\mathrm{i}$ Indstiftelsesordene. Vandet og brødet og vinen er både uden for og inden for kirken for billeder at regne. Anderledes forholder det sig med sagen selv: ". . for at faae Brød og Viin til at betegne og betyde al muelig aandelig Næring, Styrkelse og Vederkvægelse behøve vi ligesaalidt at troe Herrens Ord i Nadveren, thi saadanne Skygge-Billeder er disse 
Ting i sig selv, saavel i Verden, som i Kirken, saavel uden Ord som med Ord, men naar det derimod er os om Tingene selv at giøre om Synds-Forladelse nemlig og det evige Liv, see, da nytter alle Tegn og Skygger og Skin os slet ikke, saa naar Herren siger til os Fred vare med eder, da maae vi nødvendig troe at Freden, som Han siger, virkelig er der og virkelig er vores, og naar Han rækker os Brødet og Kalken med de Ord dette er mit Legeme og Blod tager, æder og drikker, da maae vi ligesaa nødvendig tage Ham paa Ordet og troe at Hans Livs-Kraft virkelig er der og virkelig er vores med Brødet og Vinen, saa vi virkelig komme til at leve med Ham, som døde for os -".

Når fredlysningen (et af Grundtvigs centrale ritualord, se den hermeneutiske model) lyder, skal vi tro, at freden virkelig er til stede, men når nadverordene siges, skal vi tage Herren på "Ordet« og tro, at hans kraft er til stede og er vores med brø̈det og vinen. I modsætning til freden er brød og vin snarest ledsagefænomener, der skal præcisere "Ordet», for selv "med Ord" er brødet og vinen kun skyggebilleder.

Sexagesima-prædikenen ligger uden tvivl bag ved salmen i nr. 95 i Sang-Værkets første bind. Heftet med bl.a. denne salme udkom kort tid efter, den 11.februar 1837. Salmen lader sig næppe forstå uden på baggrund af den lidenskabelige diskussion i prædikenen. Der tærikes især på de to første vers, der overvejer betydningen af uddelingsordene på Grundtvigs tid: "Dette er Jesu sande Legem/Blod «. Disse kontant mente ord måtte helt naturligt i ritualet være den største anstødssten for det nadversyn, som Grundtvig nu omsider så utvetydigt tør vedkende sig:

Kiender du Bordet, Hvor Man af Ordet

Æder og drikker for evig sig mæt;

Lad paa "det Sande"

Falskheden strande!

Sandhed har altid guddommelig Ret!

Brødet, Man bryder

Altid betyder

Sjælenes Føde: det himmelske Brød; 


\author{
Af alle Bægte \\ Himmel-Brød agte \\ Er dog kun Ordet, som end bliver Kiød!
}

Det er nok en gang er og betyder, der står i centrum. Jesu sande legeme og blod er altså at finde i "Ordet«. De ortodoxe uddelingsord er totalt omtolkede!

Opstemtheden i forbindelse med "den græske vækkelse» når, som det var at vente, sit højdepunkt omkring påsken 1837, for det var de græske påskesalmer, der ganske særligt havde fanget Grundtvigs opmærksomhed. Det kommer især skærtorsdagsprædikenen den 24. marts 1837 (vel Grundtvigs betydeligste skærtorsdagsprædiken) til gode. Begejstringen for den græske kirke giver Grundtvig mod til at hæve sig op over de konfessionelle grænser: "Naar derfor vore Med-Christne bekiende at de troe, Herren er virkelig tilstæde ved sit Bord og giver hvad han byder i sit Ord, da maae vi aldrig yppe Kiv eller føre Tvist med dem om Maaden, som nødvendig er dunkel for os alle, saa Enhver maa have Lov til at forestille sig det som han bedst veed og kan, uden at vi maae opkaste os til Dommere over andres Samvittighed - Det Eneste Kiærlighed i denne Henseende driver os til, er naar vi finde Forestillingen vrang og farlig, da, efter den Viisdom os er givet og i den Knude vi er sat, at advare derimod, og anbefale en Forestillings-Maade, som vi har erfaret, sømmer sig bedre og hjælpe til at giøre Maaden frugtbar. Der har saaledes og er endnu i Christenheden ikke blot Tvist om Herrens virkelig Nærværelse, men ogsaa forskellige Meninger om Nærværelsens Maade og medens disse alle maae taales, kan vi dog kun billige og anbefale en af dem. - Nogle siger nemlig at Herrens Legeme og Blod vel er virkelig men kun aandelig tilstæde $i$ Nadveren, medens Andre paastaae at Brødet og Vinen under Velsignelsen forvandles til Christi Legeme og Blod og endelig stræbde Morten Luther og vore Fædre at gaae en Middelvei, sigende at der vel ingen Forvandling skedte, men at dog Herrens Legeme og blod annammedes i, med og under Brødet og Vinen - Af disse Forestillings-Maader maa jeg kalde den Første slibrig, den anden farlig, og den Tredie lidt forvirret, og mener, at alle Christne, som troe paa Herrens virkelige Nærværelse kunde og skulde enes om, at hvad vi veed eller kan vide om Nærværelsens 
Maade, er at det er Herrens Ord, hvorpaa den ene og alene beroer, saa Nærværelsen maa forsaavidt nødvendig siges at være aandelig, men er derfor ingenlunde ulegemlig, da Ordet er legemligt saavelsom aandeligt og binder sig selv til Brødet og Vinen, som Aanden derfor ogsaa ved Apostelen Paulus kalder Legemets og Blodets Samfund eller Fællesskab Amen i Jesu Navn Amen! .

Her får vi endelig svar på spørgsmålet: hvor er Herrens legeme i nadveren? i Ordet! Ordet er både legemligt og åndeligt.

Dette grundtvigske særstandpunkt gjorde indtryk på den engelske konsulatspræst i Helsingør, Wade, der den 26. marts 1835 var til middag hos Grundtvig. Han spurgte ham ud fra sin kirkelige baggrund i England (en udbygget nadverlære) ud - sikkert som vi ville have gjort det, f.eks. om nadveren. Wade skriver $\mathrm{i}$ sin dagbog: "on Lords Supper - he is positive upon a real presence takes that to be the word which he says is a body and considers the words of Christ in sacrament to be is his bodily presence ... and that those who believe not receive but only receive him to crucify him afresh ..." (Grundtvig-Studier 1948, s. 51).

Wade's dagbogsoptegnelse er måske en af de mest præcise beskrivelser af Grundtvigs klart formulerede nadversyn og viser, at synet allerede eksisterede før 1837.

Guds-ordet som Guds legemlighed just i nadveren kommer iøvrigt frem netop i Herre, hvor skal vi gå hen, den salme, der ellers traditionelt tolkes i modsat retning - nemlig i vers $10 \mathrm{i}$ den oprindelige version i Sangværket, bind 1, nr. 100, hvor det til menneskets sjæl og legeme siges:

Sjal og Legem, begge To!

Enes kiønt i Hjertets Tro!

Enes om at tro Guds Ord,

Hvori legemlig Han boer,

Guders Gud og Fader kaldt,

Som er evig Alt i Alt!

Netop Grundtvig kunne som den evangeliske ritualist udtrykke sig sådan. Guds ord var jo ikke hvad som helst. Det var fortættet $\mathrm{i}$ ritualordene og ganske særligt i de dybt personlige ord, 
d.v.s. de tilsigende, tilspørgende og befalende vendinger. Denne fortætning er jo nærmest at ligne ved en legemliggørelse.

Der er derfor ingen, der som Grundtvig har kæmpet for sakramenternes og især nadverens ordkarakter. Det kommer bedst frem i salmerne. Vi kender alle eksempler på det. Grundtvig kan ikke komme tæt nok på ordet. Undertiden er sproget simpelthen ved at gå i stykker for ham, når han skal udtrykke hemmeligheden:

Jesus Christus over Bordet,
I den Nat, han blev forraadt,
Brødet brak og deelde Ordet,
Hvori evigt Liv er saaet,

(III 114,4)

Det Brød, som brydes paa dit Bord,

Det er din Faders Guddoms-Ord,

Det er dig selv med Liv og Aand,

Livs-Brødet af Guds Fader-Haand.

(III 192,2)

Saatit vi mødes ved dit Bord,

Lad mætte os dit Guddoms-Ord!

Og lad os i dets klare Vin

Inddrikke Barneglæden din!

(III 192,21)

For én overfladisk betragtning er det jo en reformert tankegang, hvis man overser, at Ordet for Grundtvig som sagt ikke er hvad som helst, men en koncentration af evangeliets nådestilsigelse $\mathrm{i}$ ritualets helt bestemte ordlyd. Ordet er noget givet og objektivt. Ordet er legemligt.

Ordkarakteren fremhæves af Grundtvig i prædikener og salmer på den måde, at de personligt tiltalende ritualord citeres tydeligt og sættes med anførselstegn og med kursiveringer. Når f.eks. salmen Herre, hvor skal vi gå hen misforstås mod sin hensigt, hænger det bl.a. sammen med, at salmebogen ikke tåler den slags excesser. Ordet fremhæves i nadveren på elementernes bekostning, mest fordi ordet hele tiden skal fastholdes som Herrens ord alene.

Det er derfor typisk nok Herrens personalnærvær, Grundtvig 
i forlængelse heraf fremhæver, just ikke mystisk, for nærværet er jo blevet verbaliseret: Indstiftelsesordene ",,skal naturligvis minde en Kristen baade om Herrens Bord og om vort eget: om Herrens Bord, hvis Velsignelse først og fremmest beror paa, at vi tro, det er ham selv, som takker, velsigner og uddeler, skjønt vi se ham ikke, men høre kun hans Røst; og om vort eget Bord, hvor vi ogsaa nødvendig med Taksigelse maa modtage og uddele det daglige Brød som Guds Gaver, dersom det skal være os velsignet" (Prædikener...i Frederiks-Kirken 1832-39, side 515).

Eller sagt med et salmevers:

For øjet skjult, for hånden tom

du vandrer i din helligdom, men kendes dog på røsten din, når du velsigner brød og vin.

(DDS 426,4)

Grundtvig går på dette punkt et skridt videre end Luther, der blev $\mathrm{i}$ den indsnævring, som den katolske nadverpraxis havde efterladt ham i, nemlig Indstiftelsesordene og nadverelementerne uden indramning af nogen art.

Ved nadveren er Gud Herren selv til stede. Og der er et bord, hvor Gud selv sidder for bordenden:

Der er et himmelsk Giæstebud

Beredt for os hernede,

Og Værten er den gode Gud, som Dug for os vil brede

Selv om vægten ved altergangen ligger på værtens ord, vil Grundtvig jo ikke benægte, at man făr noget at spise, men det er det guddommelige måltids naturlige bestanddele, det helt ovenud gode. $\mathrm{Vi}$

Smage ved Hans Bord paa Tue Livets Brød og Glædens Drue! 


\author{
Men Vorherres Brød og Viin \\ Med hans Lyst og Glæde \\ Er for Hjertet Føde fiin \\ Paa hans Høibords-Sæde, \\ Thi hans Glæde uden Ruus, \\ Stammer fra Gud-Faders Huus, \\ Kærlighedens Glæde!
}

Hermed fremhæves et andet vigtigt moment: Grundtvig kan uden vanskelighed tale om brød og vin ved nadveren som den naturlige mad; det fremgår af talrige eksempler, som enhver bruger af salmebogen kender.

Med udgangspunkt bl.a. i prædikenen på septuagesima søndag 1835 (Prædikener... i Frederiks-Kirken 1832-39, side 222ff.) vil Kaj Thaning hævde, at Grundtvig under indtryk af Irenæus "antignostisk " gør op med sit romantiske billedsyn (Menneske først - Grundtvigs opgør med sig selv, side 549). For nadverens vedkommende ville det betyde, at brød og vin som udtryk for skaberværket har en legemlig virkning ved altergangen - en tankegang, der ihvertfald ikke lader sig forlige med de konklusioner, der ovenfor er draget.

Men billedsynet består, ja frigøres måske tilmed af Grundtvigs syn på Ordets legemlighed. Her kan inddrages de anførte passager fra sexagesima-prædikenen fra 1837. I denne sammenhæng skal jeg iøvrigt blot henvise til stud. theol. Leif Kallesens specialafhandling fra 1975: Grundtvigs nadveropfattelse med særligt henblik på nadverelementerne og realpræsensen i forhold til den lutherske, den irenæiske og den nytestamentlige tradition (udarbejdet under et pågående Grundtvig-seminar på Århus Universitet), en afhandling, der i høj grad fortjener at blive publiceret. I en række indtrængende analyser gør Kallesen overbevisende gældende, at den omstændighed, at det legemlige tilkendes realitet, ikke er ensbetydende med, at billedsynet opgives, og den anførte septuagesima-prædiken kan ses som et forsøg på at kombinere Irenæus' positive forhold til det legemlige og billedsynet. Især i poetiske udtryksformer smelter det afbildede og det afbildende let sammen. Hertil kommer, at billedsynet er integreret i Grundtvigs frelsesforståelse.

Hermed kom altergangen ud af den langfredagsdragt, som Luther ikke frigjorde den fra, fordi han var bundet af den katolske indsnævring og foretog sit opgør just på dette punkt. Selv om vi her har undersøgt Grundtvig med det lutherske nadversyn som udgangspunkt, må det ikke overses, at der er andre sider af Grundtvigs nadversyn, der ikke kommer så stærkt frem ved en sådan sammenligning. Det gælder især de sidste momenter, der her skal anføres. 
Grundtvig fremhæver fallesskabet i to betydninger, fællesskabet med Gud og fællesskabet med næsten. Det sidste fællesskab spillede en stor rolle for Luther i nadversermonen fra 1519, men gled senere ud til fordel for andre anliggender. Hos Grundtvig dukker motivet op med stor kraft. Ordet legeme kan han netop bruge i den gamle paulinske betydning, som hos Paulus klinger med, når han i 1 . Kor. kap. 11 som den første gengiver Jesu ord: dette er mit legeme:

Med Vorherre ved hans Bord

Fællesskab har vi, som troer,

At hans Menighed forvist

Er hans Legem her og hist!

I den mærkelige utrykte skærtorsdagsprædiken fra $\overline{1843}$ tager Grundtvig sit udgangspunkt i Paulus' ord: Han har gjort, at hele menneskeslægten, som bebor jordens kreds, er af ét blod (frit efter Ap.G. kap 17). Hvad der var en given ting fra og med skabelsen fuldkommes ved nadveren:

"Det er dog først ved Herrens Bord det maa slaae alle Christne, at de nødvendig maae betragte hele Menneske-Slægten som Børn af eet Blod, da Christendommen ellers umuelig kunde strække sig til alle Folk under Himmelen, thi hvor den kommer hen mellem Sorte og Hvide, siger Herren ved sit Bord: dette er mit Blod, drikker alle heraf, thi heraf følger nødvendig, at hele Menneske-Slægten baade kan og skal være af eet Blod, og det er soleklart, at hvem der ikke engang kan finde sig i, at Menneske-Slægten ved Udspringet fra de samme første Forældre, paa naturlig Maade har eet Blod, de finde sig langt mindre $i$ at de Troende af alle Slags Folk under Himmelen, paa overnaturlig Maade blive af eet Blod, naar de delagtiggiøres i den Velsignelsens Kalk, som er Christi Blods Samfund."

Eller med et salmevers:

Halleluja i Fællesskab

Med alle dem fra Hav til Hav,

Som Sandheds Aand med Naadens Ord

Forsamler om Vorherres Bord.

(V 112,12) 
Et notabene til disse ubetingede udtalelser om fællesskabet er naturligvis Grundtvigs uafladelige tale om det rene nadverbord. Vanealtergangen får sin sag for, praktisk talt hver gang Grundtvig skal prædike 2. søndag efter trinitatis (det store gæstebud). Dels overvintrer en gammel pietistisk holdning hos ham, selv om den står ret uformidlet i forhold til den mere ubetingede tale om fællesskabet. Dels kæmper Grundtvig hele sit liv for altergangens befrielse fra den borgerlige tvang, at man skulle til alters, for sine borgerlige rettigheders skyld. Det er på dette sidste punkt, man efter min mening bl.a. skal finde baggrunden for Grundtvigs vedholdende angreb på vanealtergangen.

Nadveren bliver endvidere lovsang. Det er ikke nødvendigt at eksemplificere det nærmere, men for Grundtvigs samtid har det været en revolution, hvis man ser på karakteren af de salmer, der traditionelt stod omkring ritualet. Ja, det gælder mange steder endnu, at de drøvelige salmer har fortrinsret ved altergangen, selv om Grundtvig har givet os den gamle eukaristiske tone tilbage:

$$
\begin{aligned}
& \text { Halleluja for Herrens bord, } \\
& \text { i Himlen hist og her på jord! } \\
& \text { Halleluja, stig op, stig ned } \\
& \text { for Jesus, i al evighed! }
\end{aligned}
$$

Hermed har jeg allerede indirekte nævnt det sidste perspektiv, som Grundtvig gengiver nadveren, nemlig det eskatologiske. Nadveren er her og hist det himmelske måltid.

Her gælder det, at vi

bygge kun et gæstekammer

til en himmelsk altergang!

(DDS 306,6)

Himmel og jord bliver ét:

Guds Engle, de farer op og ned

Med Brød og Viin og Glæde,

Og lære Vorherres Menighed 
At nynne og at kvæde:

Hos Herren vi drikke Lys og Fred,

Og evigt Liv vi æde!

Et vers, der samler alle de indtil nu omtalte motiver. Eller

Da føle vi, du bor ej blot

i Guds, vor Faders gyldne slot, men også i det hus af jord, hvor vi gå til vor Herres bord!

(DDS 426,6)

Nadveren er en forsmag på himmeriget, sådan som det fx. siges i det sidste og desværre udeladte vers af salmen Går det, Herre som jeg vil:

Da os vinke rundt om Bord

Davids-Borgens Stole,

Da i Glansen af Guds Ord

Skal sig Støvet sole,

Hjertet med Forundring stor,

Lære alt på denne Jord,

Naar Han er hos Sine,

Glemmes Død og Pine!

I himlen er der et bord og et bordfællesskab. Himmeriget er Guds fest, sådan som Herren selv lovede det:

Ja, selv naar udtømmet

Er Kalken paa Jord,

Og atter indstrømmet

I Englenes Kor,

Skal selv i Guds Rige

Sig rejse det Bord,

Thi aldrig kan svige

Et Sandhedens Ord,

Og sagde han ikke:

Det $\mathrm{Ny}$ vil jeg drikke

Med eder i Faderens Land! 
Det er da også det bord, Grundtvig selv stævner imod tværs igennem tvivl og anfægtelse:

Naar med denne Verden brydes, Til Guds-Bordet vi indbydes!

Både dåben og nadveren blev hjemlige og fortrolige for Grundtvig. Dåben blev beskrevet som den favn, barnet søger tilbage til, og nadveren som det bord og det fællesskab, som han kendte så godt. I dåben genoplever han barnets tryghed - i nadveren forudgriber han endetidens lyksalighed.

Grundtvig trækker nadveren ud af indsnævringen ved som hovedsagen at pege på de umiskendelige ord, hvormed Herren selv for bordenden indbyder os og beder til bords. Det er det glade festmåltid, hvor lovsangen slår tonen an. Det er det inderligste fællesskab, vi har med Herren og med hinanden. Det er himmerig på jord. Det er Guds tid, den tid, som han snart vil fylde helt ud.

Hvordan skal man så karakterisere Grundtvigs nadversyn? Er han katolik, lutheraner eller reformert? Eller noget helt fjerde?

Jeg har valgt at spørge, om Grundtvigs nadversyn er luthersk.

I den forbindelse støder vi straks på den vanskelighed, at Grundtvig næppe har taget Luthers opgør med sværmerne alvorligt. Han holder sig til den Luther, han kender fra de tidlige nadverskrifter 1519-20 og den lille katekismus. Det har vi flere vidnesbyrd om.

Det gælder vel for det 19. århundrede overhovedet, at man næppe forstod Luthers fastholdelse af realpræsensen i slutningen af 1520erne. Man opfattede det oftest som et tilbagefald til en eller anden form for katolsk magi.

Hvis man derimod med en lutherforsker som Erwin Metzke i bogen Sakrament und Metaphysik (1949) mener, at Luther netop i dette opgør formulerede sin egen virkelighedsforståelse, stiller sagen sig anderledes.

Kristi nærvær i brød og vin sætter en absolut grænse for den menneskelige tænknings mulighed for at erkende Guds virkelighed, ja stiller spørgsmål til den menneskelige erkendelse, der vil 
bestemme, hvor og hvordan Gud skal være. Luther bryder med den dualistiske antropologis og metafysiks aristotelisme og den senmiddelalderlige rationalisme og spiritualisme, der også levede videre hos sværmerne. Luther bryder med den traditionelle rumtænkning. Kristus ved Guds højre hånd er overalt til stede. Han opgår ikke i skabningen, men står over den. Selv om ordene: dette er mit legeme ikke lød, var han alligevel til stede i alt brød på alle borde. Derfor er forvandlingen unødvendig. Hermed skaber Luther et nyt forhold for mennesket såvel til den naturlige som til den guddommelige virkelighed. Det bliver ét og det samme umiddelbare forhold - ligetil og uspekulativt. Guds almagt skal ikke gøres himmelsk for at blive jordisk forstået. Guds åbenbaringsmagt bryder ikke ind $i$ verden, men er der allerede - unddraget menneskers magt og tænkeevne.

Kristi legemlighed er afgørende for Luthers forståelse af legemlighed overhovedet. Med Kristus falder alle hovmodige forsøg på at adskille åndeligt og legemligt, her og hinsides. Kristi legemlighed befrier Luther til verden, som den er. Kristi legemlighed afslører menneskets dybe trang til at åndeliggøre Gud og dermed unddrage sig den konkrete virkelighed.

Luthers karske nadverforkyndelse nåede ikke Grundtvig. Den gik til grunde i ortodoxien, velsagtens fordi Luther i dette gigantiske opgør blev stående $\mathrm{i}$ den indsnævring, som den katolske messe havde anbragt ham i, med brød og vin og indstiftelsesord og intet andet.

Eftertiden kunne ikke fastholde det syn. Den faldt tilbage i spekulationer om den pneumatiske spise eller lagde ved altergangen vægten på inderligheden $\mathrm{i}$ den personlige modtagelse eller begge dele på én gang. Luthers virkelighedstroskab som bondefødt og hans tanker om verdens legemlighed, der i sproglig henseende ikke var uberørt af en panteistisk mystik, fastholdt Kristi person i sakramentet. Men for eftertiden blev der et hul i nadveren, en afstand mellem nadverens det, stumperne af Kristus, kunne man sige, på den ene side og den hele Kristus, Jesu person, på den anden side. Det, der for Luther var et tydeligt og uundgåeligt udtryk for Guds nåde og evangeliet, satte sidenhen en barriere for mennesker, forsåvidt nadveren ikke blev til virkelighed, førend man personaliserede den, enten ved at lægge vægten på sin egen personlige beredelse og forventning eller det me- 
re evangeliske: ved at spejde efter Jesu person som subjekt for handlingen.

Vi er selv så meget børn af de århundreder, der har kæmpet for at formulere nadveren, at vi må erkende, vi er sat i den samme klemme den dag i dag. Vi kan godt forstå og acceptere det lutherske standpunkt historisk betragtet. Vi mærker inspirationen derfra, men har svært ved selv at komme videre.

Det er i denne sammenhæng, vi skal se og vurdere Grundtvig. Han repræsenterer efter min mening det fjerde nadverstandpunkt ved siden af de tre allerede nævnte. Eller man kan sige: Grundtvig genopdager det johannciske nadversyn, d.v.s. et syn, der kæmper for nadverens karakter af forkyndelse mod en hellig materialisme - uden at slække på nadveren som en konkret nådestilsigelse.

I det 19. århundrede står Grundtvig som den ensomme hebræer. Han hører Guds ord som de gamle jøder og kristne. Det er skaberordet, hvorpå alt beror. Det er Kristus. Det er ordet til ham. Det er Herrens ord over Vandet - ved skabelsen, ved dåben, over bordet og i fuldendelsen. På den baggrund genopdagede han livet og virkeligheden og midt i verden gudstjenesten som Guds tid - i ubrudt fællesskab med de svundne slægter på vej mod fuldkommelsen.

Han lander ikke i katolicismen eller en gold traditionalisme, for han er trods alt lutheraner. Han er ikke reformert, for Herrens nærværelse er en kendsgerning. Han er ikke lutheraner, for han tror hverken på bibelordet eller på Kristi legems og blods substantielle nærvær i brød og vin. Han tror på Guds ords legemlighed, d.v.s. på de kendte, altid gentagne, personligt vedkommende ord. Han tydeliggør den tro ved at gengive nadveren dens glemte dimensioner.

Just på troen på Guds ords legemlighed hænger Grundtvigs forhold til livet og virkeligheden. Ligesom Luther formulerede Grundtvig tydeligst sit standpunkt i et opgør med den altergang, han overtog. Luther og Grundtvig må forstås på hver sin baggrund og Grundtvigs forhold til det 19. århundrede er og bliver kompliceret. Og med det forebehold må spørgsmålet om, hvorvidt Grundtvigs nadversyn var luthersk, besvares med et nej, hvis man tager sit udgangspunkt i konfessionelle formuleringer, 
men snarest med et ja, hvis man vil se mere på motiver end på tidsbestemte formuleringer.

Hvor intet andet er anført, er prædikenerne citeret efter håndskrifterne i Grundtvig-arkivet.

\section{Noter}

1. Foredrag holdt ved Grundtvig-Selskabets årsmøde i Århus 1973. Lidt udvidet.

2. Jf. min afhandling: "De levendes Land" og prædikenerne sommeren 1824. Prædiken og salme hos Grundtvig I (Dansk Kirkesangs Årsskrift 1971-72, side $122 \mathrm{ff}$.).

3. Jf. min afhandling: Om Grundtvigs salme "Herre, hvor skal vi gå hen " (Hymnologiske Meddelelser, 3. årg. 1974/1, side 18 ff.).

4. Til fremstillingen $i$ det flg., se min afhandling: Prædiken og salme hos Grundtvig III: Omkring Sang-Værkets første bind 1836/37 (Dansk Kirkesangs Årsskrift 1973-74). 